\title{
MAKING AND TESTING SAMPLE CONTROL ON DETERMINATION OF NITRITE CONTENT IN WATER AND WASTE WATER BY USING UV-VISIBLE SPECTROPHOTOMETER
}

\author{
Erna Styani ${ }^{1}$, Endang Sri Lestari ${ }^{2}$, Ika Widiana ${ }^{3}$ and Muhammad Ramadhan ${ }^{4}$ \\ Polytechnic of AKA Bogor, Industrial Human Resources Development Board \\ Ministry of Industri Republic of Indonesia \\ Jl Pangeranan Sogiri 283 Tanah Baru, Bogor, West Java, Indonesia \\ 1 ernasekarboedhi17@gmail.com, ${ }^{2}$ lestarirahadiian@ymail.com, ${ }^{3}$ widiana.ika@ gmail.com, and \\ ${ }^{4}$ ramadhanm9650@gmail.com
}

\begin{abstract}
This study focused on Making and Testing sample control as reference material on determination of nitrite content in water and waste water by using UV-Visible Spectrophotometer. Sample control has been made to replaced Certified Reference Materials (CRM) for determination of Nitrite content in water and waste water by using UV -Visible Spectrophotometer. Substitute materials for CRM should be homogeneous and stable, so the homogenity and stability control sample that has been made in this study is tested by using standard referring to ISO Guide 35,2006 . The result of this experiments shows that the values of $F_{\text {stat }}$ and $F_{\text {table }}$ on homogenity test are 0.796 and $3.179\left(\mathrm{~F}_{\text {stat }}<\mathrm{F}_{\text {table }}\right)$; while the values of $\mathrm{t}_{\text {stat }}$ and table on the stability test are 0.431 and $2.101\left(\mathrm{t}_{\text {stat }}<\right.$ table), the mean of control sample concentration is $0,0435 \mathrm{mg} / \mathrm{L}$. All test parameters have been qualified in accordance with ISO Guide 35,2006 . The result of this research shows that the control of samples on the determination of Nitrite in water and waste water by using UV-Visible Spectrophotometer can be used as substitute for CRM and reference material.
\end{abstract}

Keywords: sample control, Nitrite content, UV-Visible Spectrophotometer, Certified Reference Materials

Abstrak: Penelitian ini berfokus kepada pembuatan dan pengujian kontrol sample sebagai pengganti material dalam penentuan kadar kandungan nitrit di dalam air dan air limbah menggunakan UV-Visible Spectrofotometer. Kontrol sampel telah dibuat untuk menggantikan Certified Reference Materials (CRM) pada penentuan kandungan Nitrit dalam air dan air limbah dengan menggunakan Spektrofotometer Sinar Tampak. Homogenitas dan stabilitas kontrol sampel yang telah dibuat diuji dengan menggunakan standar yang mengacu pada ISO Guide 35, 2006. Hasil percobaan ini menunjukkan bahwa nilai $F_{\text {stat }}$ dan $F_{\text {table }}$ pada uji homogenitas adalah 0,796 dan 3,179 ( $\left.F_{\text {stat }}<F_{\text {tabel }}\right)$; sedangkan nilai tstat dan ttabel pada uji stabilitas adalah 0,431 dan 2,101 $\left(t_{\text {sta }} t<t_{\text {tabel }}\right)$, rata-rata konsentrasi sampel kontrol adalah 0,0435 mg / L. Semua parameter uji telah memenuhi syarat sesuai dengan ISO Guide 35, 2006. Hasil penelitian ini menunjukkan bahwa kontrol sampel pada penentuan Nitrit dalam air dan air limbah dengan menggunakan Spektrofotometer Sinar Tampak dapat digunakan sebagai pengganti CRM dan bahan acuan.

Kata Kunci: kontrol sampel, kandungan Nitrit, Spektrofotometer Sinar Tampak, Bahan Referensi Bersertifikat

\section{INTRODUCTION}

The accuracy test data was proved by the standard deviation value of the repetition results of an analysis, whereas for the accuracy of laboratory data must have reference materials, such as Certified Reference Materials (CRM). The reference material is one or more quantitative values known with certainty the content (in the form of true value or assigned value) is contained in the form of certificate.

The price of the certified reference material is relatively expensive, so the laboratory is not always possible to use CRM for daily analysis in proving the accuracy of the data, so that the sample control as an alternative substitute of reference material was used. Sample control is a reference material made by a laboratory used as a monitor of routine measurement analysis quality.

Several studies related to CRM have been carried out such as "Value Determination of Geochemical In-House Reference Material with Andesite Matrices from Hargorejo Kulon Progo" (Irzon, 2018) and Analysis Methods for Development of Certified Reference Material (CRM) Zircon Minerals Synthesis (Samin and Sunanti, 2018).

This experiment purposes was to create and tested samples control that had 
been made to be used as a substitute of reference or CRM on the determination of nitrite levels in water and waste water by UV-Vis Spectrophotometry (Gandjar, 2007). Replacement of the reference material should be homogeneous and stable, so that the homogenity and stability of the sample control shall be tested in accordance with ISO Guide 35 of 2006 (Taylor, 1996).

\section{MATERIAL AND METHODS}

The experiment consists of three stages: preparation, testing, and data processing. Preparation consists of preparation of nitrite sample control $0,05 \mathrm{mg} / \mathrm{L}$, making nitrite stock solution $250 \mathrm{mg} / \mathrm{L}$, making of nitrite standard solution $0,50 \mathrm{mg} / \mathrm{L}$, making of nitrite stock solution $100 \mathrm{mg} / \mathrm{L}$, making of color reagent, and making of series nitrite standard.

The step of Making sample control can be seen in Figure 1. as bellow.

Step 1

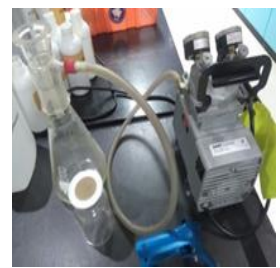

The Surface water was filtered (initial nitrite content of 0.009 $\mathrm{mg} / \mathrm{L}$ ) and then loaded into empty and clean container

Step 2

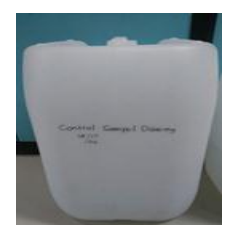

Added with 100 ppm stock solution and homogenized

Step 3

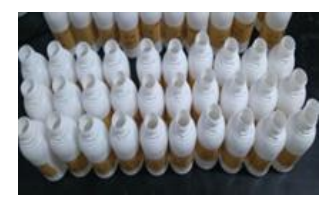

Disposable PE Bottle was prepared and labelled

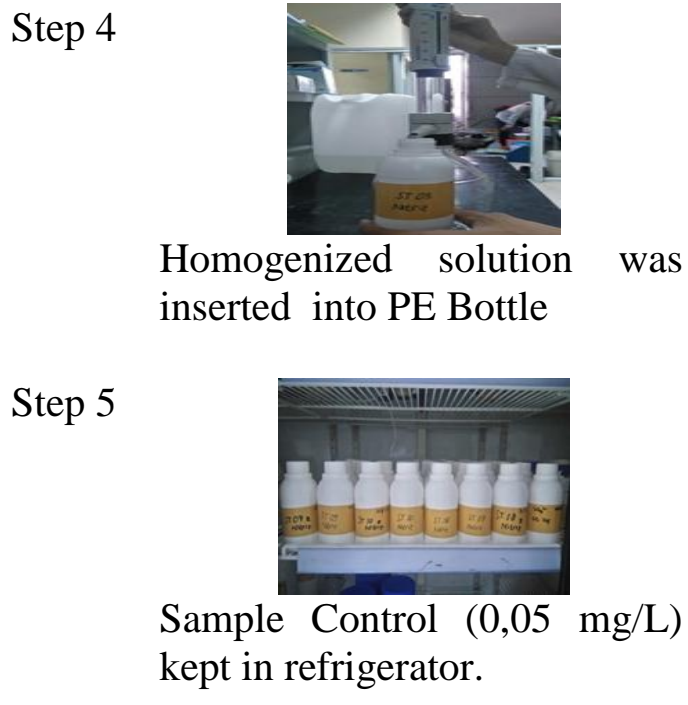

Figure 1. The Step of Making Sample Control

The sample control solution that has been made above ( Figure 1), then determined the nitrite content by pipeting $50 \mathrm{~mL}$ solution then put into $50 \mathrm{~mL}$ volumetric flask, added $2 \mathrm{~mL}$ of color reagent, shaking it and leaving it for about 10 minutes to two hours and the absorbance is measure at a wavelength of $543 \mathrm{~nm}$. The coloring reagents used in nitrite content determination can be made by added 50 $\mathrm{mL} 85 \%$ phosphoric acid and $5 \mathrm{~g}$ sulfanilamide into $400 \mathrm{~mL}$ distilled water. After sulfanilamide is completely dissolved, $500 \mathrm{mg} \mathrm{N}$-(1-naphthyl) ethylene diamine dihydrochloride (NED) is added, stirred until dissolved, then adjusted to 500 $\mathrm{mL}$ with distilled water. The solution store in dark bottle and in the refrigerator. (SNI 06-6989.9-2004).

The testing stage is done by determining the control level of nitrite sample (homogenity, true value, and stability). Phase data processing of the test results done statistically and displayed in the control chart.

The homogenity test had done once in each process of controlling the nitrite sample, and performed simultaneously with the first test of stability. Tests were performed with ten packaged samples randomly to be tested. The true value test was done just like the homogenity test 
done in different time. Testing on each packing was done twice repetition (duplo).

Stability testing as the first data used data analytical content of homogenity test results, then the next data was tested once a week. Tests were performed with ten packaged samples randomly to be tested. Testing on each packing was done by twice repetition (ISO Guide 35, 2006).

The method of sampling test refers to ISO 13528 in 2005 on Statistical Methods for Use in Proficiency Testing by Interlaboratory Comparisons. The sampling scheme for the determination of nitrite sample control (homogenity, true value, and stability) can be seen in Figure 2.

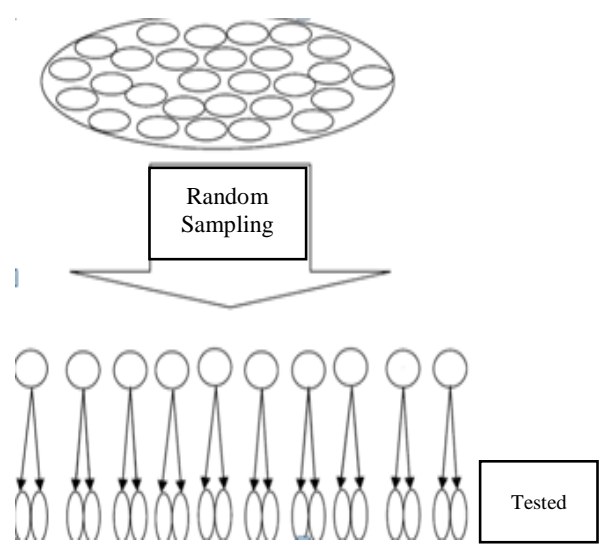

Figure 2. The Scheme of Sampling for Nitrite Sample Control Test

The homogenity of the sample is determined statistically. Based on the National Accreditation Committee, there are four criteria of homogenity, they are:
a) $\mathrm{F}_{\text {stat }}<\mathrm{F}_{\text {table }}$
b) $\frac{S_{\text {sampling }}}{\sigma}<0,3$
c) $\mathrm{S}_{\text {sampling }}<0,3 \mathrm{~S}_{\text {horwitz }}$
d) $S_{\text {sampling }}<S_{\text {horwitz }}$

If the result of homogenity test of criterion I is fulfilled, then it is not necessary to process the data on the next criteria (Komite Akreditasi Nasional, 2004).

The stability of the sample is known by the difference between the mean homogenity ("x"-_ "homogenity") and the stability ("x"- "stability") of $t$ count that compared with t table. Samples can be said to be stable if they meet the requirements, i.e:

$$
t_{\text {stat }}=\frac{\left|\overline{\mathrm{x}}_{\mathrm{H}}-\overline{\mathrm{x}}_{\mathrm{S}}\right|}{\mathrm{SD}} \times \sqrt{\frac{\left(\mathrm{n}_{\mathrm{H}} \times \mathrm{n}_{\mathrm{S}}\right)}{\left(\mathrm{n}_{\mathrm{H}}+\mathrm{n}_{\mathrm{S}}\right)}}
$$

The True Value is determined by calculating the average of the test result (true value), then compared with the target value with the acceptability of (100 \pm $15) \%$.

The control chart is a graphical display by comparing the results data on continual process to a stable and predetermined control limits of the previous performance data. Sudijono (2010) explained that control limits on the control chart consists of :

a) Upper control limit (UCL) $\left(\mathrm{x}^{-}+3 \mathrm{SD}\right)$

b) Upper warning limit (UWL) ( $\mathrm{x}^{-}$ 2SD)

c) Lower warning limit (LWL) $\left(x^{-}-2 S D\right)$

d) Lower control limit (LCL) $\left(x^{-}-3 \mathrm{SD}\right)$

Control sample solutions that have been made can be use as substitute CRM if all test parameters were in compliance with ISO Guide 35 of 2006., with the homogenity value $\mathrm{F}_{\text {stat }}<\mathrm{F}_{\text {table }}$ and the value of stability $t_{\text {stat }}<$ table.

\section{RESULT AND DISCUSSION}

Nitrite levels in surface water were determined using UV-Vis Spectrophotometry (Effendi, 2003). Nitrite compounds in surface water are usually found in very small amounts in the water over nitrate, because nitrites are unstable in the presence of oxygen, which will immediately be oxidized become nitrate (Achmad, 2004).

Each analysis performed requires a calibration curve to prove the existence of a linear relationship between the concentration and the response of the device. The calibration curve shows the ability of the analysis method to produce a response proportional to the concentration of the analyte in the sample in the range or range that exists (Hadi, 2007). The 
calibration curve is obtained from the relationship between concentration value and the tool response. Results The calibration curve on the determination of nitrite in water and wastewater can be seen in Fig 3.

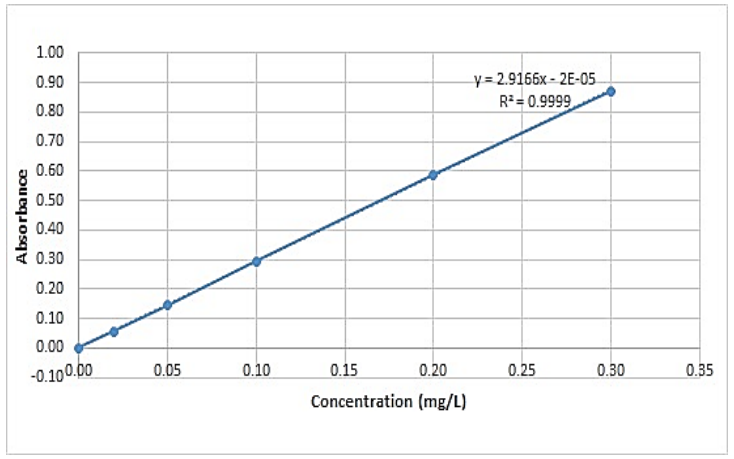

Figure 4. Calibration Curve of Nitrite Determination in Water and Wastewater

As the regression line that showed from figure 4 , the obtained correlation value was 0.9999 . The test results proved that there was a linear relationship between the method with the tool response and qualify acceptance of correlation, that was $r \geq$ 0.9950. Based on the nitrite determination calibration curve, the obtained slope value was 2.9166 and the intercept value was 0.00002 , so that the equation obtained by regression line was $\mathrm{y}=-0,00002+$ 2,9166x.

In the experimental process and testing of sample control on the determination of nitrite in water and wastewater by UV-Spectrophotometer light was tested to the test material to find out the requirements that fulfilled as quality qontrol on sample control. The tests conducted were: homogenity, stability, and true value (Sudijono, 2010).

Homogenity test is a test that aims to know the dissemination of analyte in the sample before being used in the test. The spread of the analyte evenly on the reference material is very important, since the non-homogeneous reference material will yield mixed results and has no true value. Homogenity test was done by comparing the variety of two data, commonly called the $\mathrm{F}$ test. The homogenity test results can be seen in Table 1.

According to the homogenity test results which is shown on Table 1 , the obtained Fcount value is 0.80 and the Ftable of 3.18 has $95 \%$ confidence level. Meanwhile, according to the experimental obtained value, the sample control meets the criterion I, that is Fcount is less than the Ftable value, so the material can be said homogeneous. The results of the experiments also showed that the dissemination of the analyte in the test material was evenly distributed throughout the sample so that further analysis can be performed.

Stability test is a test that aims to determine the effect of time on the concentration of analyte in a test material. The stability test had an important role in testing the control of the sample, because it showed that the analytical concentration did not change significantly if it was stored for long periods of time. This was to ensure the quality of the control samples that have been made. The stability test was calculated statistically by comparing two independent data sets which called t tests. The results of stability testing can be seen in Table 2.

According to the results of stability test in Table 2, the obtained tcount value is 0.431 and table value is 2.101 with $95 \%$ confidence level. Based on the test value, the test material has met the stipulated requirements, that is the value of tcount is smaller than the table value. 
Table 1. Homogenity Test Result

\begin{tabular}{|c|c|c|c|}
\hline \multirow{2}{*}{$\begin{array}{l}\text { Sample } \\
\text { Number }\end{array}$} & \multicolumn{2}{|c|}{ Repetition } & \multirow{2}{*}{$\begin{array}{c}\text { Acceptance } \\
\text { Requirements }\end{array}$} \\
\hline & $\begin{array}{l}\mathrm{NO}_{2} \\
(\mathrm{mg} / \mathrm{L})\end{array}$ & $\mathrm{NO}_{2}(\mathrm{mg} / \mathrm{L})$ & \\
\hline 1 & 0.0432 & 0.0436 & \multirow[t]{10}{*}{$\mathrm{F}_{\text {stat }}<\mathrm{F}_{\text {table }}$} \\
\hline 2 & 0.0436 & 0.0439 & \\
\hline 3 & 0.0436 & 0.0432 & \\
\hline 4 & 0.0432 & 0.0432 & \\
\hline 5 & 0.0432 & 0.0436 & \\
\hline 6 & 0.0436 & 0.0432 & \\
\hline 7 & 0.0436 & 0.0436 & \\
\hline 8 & 0.0432 & 0.0432 & \\
\hline 9 & 0.0442 & 0.0432 & \\
\hline 10 & 0.0436 & 0.0432 & \\
\hline Mean Square Between & \multicolumn{3}{|c|}{$6.60 \times 10^{-8}$} \\
\hline Mean Square Within & \multicolumn{3}{|c|}{$8.29 \times 10^{-8}$} \\
\hline $\mathrm{F}_{\text {stat }}$ & \multicolumn{3}{|l|}{0.80} \\
\hline$F_{\text {table }}$ & \multicolumn{3}{|l|}{3.18} \\
\hline
\end{tabular}

The t-test material values which smaller than the table indicated that the analyte concentration on the reference material had not changed significantly for two months of storage and was stable.

The true value test is a series of tests to ascertain the true value of analytical concentrations contained in the test material. In the conducted experiments, the measured initial nitrite content of the test material (surface water) then was known to have of $0.009 \mathrm{mg} / \mathrm{L}$. The test material was added with a $100 \mathrm{mg} / \mathrm{L}$ nitrite parent solution to obtain a level of $0.050 \mathrm{mg} / \mathrm{L}$. The true value test results can be seen in Table 3.

Table 2. Stability and Homogenity Test Result

\begin{tabular}{|l|l|l|l|}
\hline Week & \multicolumn{1}{|c|}{$\begin{array}{c}\text { Mean Stability } \\
(\mathbf{m g} / \mathrm{L})\end{array}$} & \multicolumn{1}{|c|}{$\begin{array}{c}\text { Mean Homogenity } \\
(\mathbf{m g} / \mathrm{L})\end{array}$} & $\begin{array}{c}\text { Acceptance } \\
\text { Requirement }\end{array}$ \\
\hline 1 & 0.0437 & 0.0434 \\
\hline 2 & 0.0434 & 0.0437 \\
\hline 3 & 0.0436 & 0.0434 \\
\hline 4 & 0.0437 & 0.0432 \\
\hline 5 & 0.0437 & 0.0434 \\
\hline 6 & 0.0437 & 0.0434 \\
\hline 7 & 0.0436 & 0.0436 \\
\hline 8 & 0.0436 & 0.0432 \\
\hline 9 & 0.0439 & 0.0437 \\
\hline 10 & 0.0432 & 0.0434 \\
\hline Mean & 0.0436 & 0.0434 \\
\hline$S D$ & 0.0002 & 0.0002 \\
\hline$t_{\text {stat }}$ & 0.431 & & \\
\hline $\mathrm{t}_{\text {tabel }}$ & 2.101 & & \\
\hline
\end{tabular}


Based on the test results in Table 3 , the actual values of the test materials had been added by $100 \mathrm{mg} / \mathrm{L}$ main nitrite solution of $0.0435 \mathrm{mg} / \mathrm{L}$. Then the obtained value did not reach the desired target value
$(0.050 \mathrm{mg} / \mathrm{L})$, due to a systematic error in adding aquadest solution slight excessively, but this did not affect the quality of the test material to serve as a sample control.

Table 3. True Value Test Result

\begin{tabular}{|c|l|l|l|}
\hline \multirow{2}{*}{ Sample } & \multicolumn{3}{|c|}{ True Value (mg/L) } \\
\cline { 2 - 4 } & Repetition 1 & Repetition 2 & Mean \\
\hline 1 & 0.0432 & 0.0439 & 0.0436 \\
\hline 2 & 0.0436 & 0.0432 & 0.0434 \\
\hline 3 & 0.0439 & 0.0439 & 0.0439 \\
\hline 4 & 0.0432 & 0.0436 & 0.0434 \\
\hline 5 & 0.0432 & 0.0439 & 0.0436 \\
\hline 6 & 0.0432 & 0.0439 & 0.0436 \\
\hline 7 & 0.0436 & 0.0436 & 0.0436 \\
\hline 8 & 0.0439 & 0.0436 & 0.0437 \\
\hline 9 & 0.0432 & 0.0432 & 0.0432 \\
\hline 10 & 0.0439 & 0.0442 & 0.0441 \\
\hline Mean & & $\mathbf{0 . 0 4 3 5}$ \\
\hline
\end{tabular}

The actual values of the test materials had been added by $100 \mathrm{mg} / \mathrm{L}$ nitrite stock solution was $0.0435 \mathrm{mg} / \mathrm{L}$. The obtained value did not reach the desired target value $(0.0500 \mathrm{mg} / \mathrm{L})$, due to a systematic error in adding aquadest solution slight excessively, but this did not affect the quality of the test material to serve as a sample control.

Table 4. Measurement Result and Acceptance Requirement

\begin{tabular}{|l|l|l|l|}
\hline Parameter & Description & Test Value & Requirement \\
\hline \multirow{3}{*}{ Homogenity } & $\mathrm{F}_{\text {stat }}$ & 0.796 & \multirow{2}{*}{$\mathrm{F}_{\text {stat }}<\mathrm{F}_{\text {table }}$} \\
\cline { 2 - 3 } & $\mathrm{F}_{\text {table }}$ & 3.179 & \multirow{2}{*}{$\mathrm{t}_{\text {stat }}<$ table } \\
\hline \multirow{2}{*}{ Stability } & $\mathrm{t}_{\text {stat }}$ & 0.431 & \multirow{2}{*}{ True value } \\
\cline { 2 - 3 } & table & 2.101 & \multirow{2}{|c}{} \\
\hline & True Value & $0.0435 \mathrm{mg} / \mathrm{L}$ & \multirow{2}{|l}{} \\
\cline { 2 - 3 } & Target Value & $0.0500 \mathrm{mg} / \mathrm{L}$ & \\
\hline
\end{tabular}

The control chart (control chart) is a statistical method to monitor the test results. This monitoring was carried out from monitoring of tools, methods, and analysts during ongoing testing. A control chart is a graphic display which compared the data that generated by the current process to a stable set of control limits that have been determined from the previous performance data. Results of the control chart data can be seen in Figure 5. 


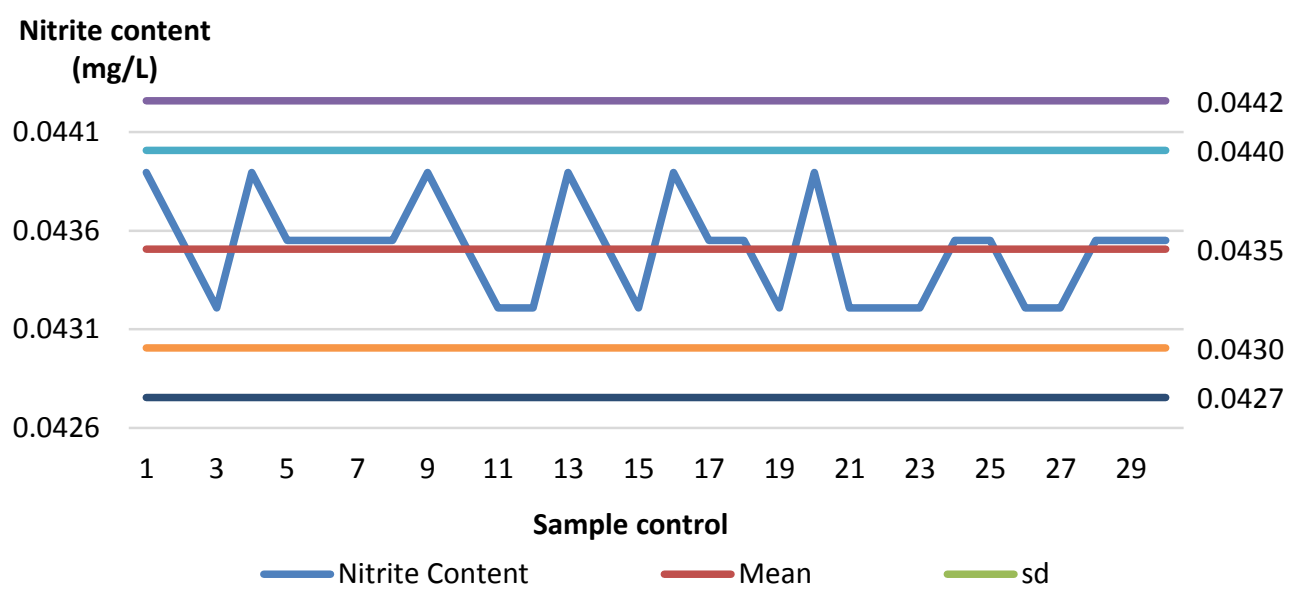

Figure 5. Control Chart of Nitrite Sample Control

According to Figure 5, the mean of the control test sample was $0.0435 \mathrm{mg} / \mathrm{L}$, UCL of $0.04426 \mathrm{mg} / \mathrm{L}$ and LCL of $0.0428 \mathrm{mg} / \mathrm{L}$ which were the upper and lower control limits. In addition, the UWL value was $0.04423 \mathrm{mg} / \mathrm{L}$ and LWL was $0.0430 \mathrm{mg} / \mathrm{L}$ which were the upper and lower warning limit.

The control chart data does not exceed the control limits or warning limits, so it can be said that the tests were under controlled conditions and no deviations were found that could interfere the analysis process.

\section{CONCLUSION}

According to the experiments that had been done, the obtained result were Fstat and Ftable value on homogenity test are 0.796 and $3.179 \quad\left(\mathrm{~F}_{\text {stat }}<\mathrm{F}_{\text {table }}\right)$. Furthermore, $\mathrm{t}_{\text {stat }}$ and table value on the stability test are 0.431 and $2.101\left(\mathrm{t}_{\mathrm{stat}}<\right.$ table). The mean of control sample concentration was $0,0435 \mathrm{mg} / \mathrm{L}$. All test parameters were in compliance with ISO Guide 35 of 2006. It can be concluded that the sample control, which has been made from surface water on this study on the determination of nitrite in water and wastewater by using UV-Visible Spectrophotometer can be used as a substitute for CRM and become a reference for routine analysis.

\section{ACKNOWLEDGEMENT}

This research was supported by Polytechnic of AKA Bogor.

\section{REFERENCE}

Achmad, R. (2004). Kimia Lingkungan. Andi Offset. Yogyakarta.

Effendi, H. (2003). Telaah Kualitas Air bagi Pengelolaan Sumber Daya dan Lingkungan Perairan. Kanisius. Yogyakarta.

Gandjar, L. G. (2007). Kimia Farmasi Analisis. Pustaka Pelajar :Yogyakarta.

Hadi, A. (2007). Pemahaman dan Penerapan ISO/IEC 17025;2005 Persyaratan umum Kompetensi Laboratorium Pengujian dan Laboratorium Kalibrasi. PT Gramedia Pustaka Utama : Jakarta.

Irzon, R. (2018). Value Determination of Geochemical In-House Reference Material with Andesite Matrices from Hargorejo Kulon Progo. Retrieved May 9, 2019 from www.academia.edu

ISO 13528. (2005). Statistical Methods for Use in Proficiency Testing by Interlaboratory Comparisons.

ISO GUIDE 35. (2006). Reference Material.

KOMITE AKREDITASI NASIONAL. (2004). Pedoman Perhitungan Statistik untuk Uji Profisiensi. Jakarta.

Samin., Susanti, S. T. (2018). Analysis Methods for Development of Certified Reference Material (CRM) Zircon Minerals Synthesis. Indones. J. Chem, 18(8), pp 448-456. 
JENV, Vol. 4, No. 1, April 2019: 1-8

SNI 06-6989.9-2004 (2004). Air dan Air LimbahBagian 9 : Cara Uji nitrit $\left(\mathrm{NO}_{2}-\mathrm{N}\right)$ secara spektrofotometri

Sudijono, A. (2010). Pengantar Statistik Pendidikan. PT Raja Grafindo Persada: Jakarta

Taylor, J. K. (1996). Quality Assurance of Chemical Measurement. Center of Analytical Chemistry. New York. 